Wpływ wysilku fizycznego na odraczanie wyplat finansowych

Michał Białek ${ }^{1,2}$ i Agata Perkowska ${ }^{1}$

1) Centrum Psychologii Ekonomicznej i Badań Decyzji; Akademia Leona Koźmińskiego, Warszawa, Polska

2) Wydziat Psychologii; University of Waterloo, Ontario, Kanada

\title{
Dane kontaktowe:
}

Dr Michał Białek

Akademia Leona Koźmińskiego,

Jagiellońska 59, 03-301 Warszawa

mbialek@kozminski.edu.pl 


\section{Streszczenie}

Zyski jak i straty zmieniają swoją subiektywną wartość wraz z rosnącym odroczeniem. Tempo tej zmiany, nazywane stopą dyskontową, określa impulsywność jednostki oraz pozwala przewidywać jej wybory, także finansowe. Badając sześćdziesiąt jeden osób przed i po ćwiczeniach fizycznych pokazaliśmy, że w wyniku wysiłku fizycznego ich stopa dyskontowa wyraźnie wzrosła. Obserwujemy zatem paradoksalny efekt wysiłku fizycznego, który - w świetle innych badań - długofalowo poprawia zdolności do samoregulacji i obniża stopę dyskontową, ale - w świetle naszych danych - krótkoterminowo przynosi dokładnie odwrotny efekt. Omawiamy wyniki w kontekście modeli samoregulacji (siłowego i zmęczeniowego) oraz alternatywnych modeli: zgeneralizowanej deprywacji, skojarzenia wysiłku z nagrodą i błędnej atrybucji.

Słowa kluczowe: samokontrola, siła woli, wyczerpanie ego, dyskontowanie, wysiłek fizyczny 


\section{Zwiazek wysilku fizycznego z odraczaniem wyptat finansowych}

\section{Dyskontowanie jako miara impulsywności decyzji}

O ile więcej jesteś w stanie zapłacić, by mieć swój wymarzony smartfon już teraz, zamiast czekać na niego kilka miesięcy i kupić go za zaoszczędzone pieniądze? Na podobne, choć nie dokładnie tak sformułowane pytanie odpowiadają sobie codziennie tysiące osób, które wahają się czy kupić jakiś produkt na kredyt. Ich decyzja polega na tym, by ocenić czy są skłonni zapłacić cenę produktu plus odsetki w zamian za uzyskanie danego produktu już teraz. Skłonność do kupna na raty wynika z tego, że wymarzony smartfon traci wyraźnie na subiektywnej użyteczności wraz z rosnącym okresem odroczenia, podczas gdy wyższa cena nie zyskuje tak silnie na dysużyteczności (sile negatywnych konsekwencji). Mówiąc krótko, subiektywna korzyść z odroczonej gratyfikacji maleje gwałtownie, a równocześnie subiektywna niekorzyść z odraczanej straty nie rośnie aż tak silnie, by to zrównoważyć. W efekcie opcja zakupu na kredyt wydaje się bardzo atrakcyjna.

To, jak wiele jesteśmy w stanie dopłacić aby uzyskać daną korzyść wcześniej (lub odczuć stratę później) jest obiektem zainteresowań psychologów i ekonomistów badających tak zwane dyskontowanie - to znaczy subiektywną zmianę wartości wypłat (zarówno finansowych jak i niefinansowych) wraz $\mathrm{z}$ odroczeniem. Wyrazem tempa tej zmiany jest stopa dyskontowa, interpretowana jako miara impulsywności decyzji. Szczególną właściwością stopy dyskontowej jest to, że jej zmiany zachodzą nieliniowo - to znaczy spadek jest najsilniejszy przy pierwszych odroczeniach, po czym jego tempo maleje wraz z kolejnymi okresami odroczenia (Laibson, 1997). Innymi słowy, istnieje duża różnica czy dostaniemy wypłatę dziś, czy za tydzień, ale istnieje tylko minimalna różnica między tym, czy dostaniemy ją za dwa lata czy za dwa lata i jeden tydzień. 
Zdolność do kierowania swoim zachowaniem tak, by postępować zgodnie z wyznawanymi regułami i normami nazywana jest w psychologii samoregulacją (Baumeister, Vohs, 2016). Osoby, które charakteryzuje wysoka zdolność do samoregulacji są bardziej skłonne do odraczania gratyfikacji, ca z kolei przyczynia się długofalowo do wyższej jakości ich życia (Moffitt i in., 2011).

Efektywność samoregulacji podlega treningowi (Muraven, Baumeister, Tice, 1999; Friese i in, 2017). Na przykład trening kontroli hamowania (np poprzez powstrzymywanie sie przed reakzją na pewnego rodzaju bodźce $\mathrm{w}$ zadaniach laboratoryjnych) poprawia obniża skłonność do przejadania się słodyczami (Houben, Jansen, 2011), a regularny trening fizyczny pozwala poprawić zdolność do odraczania natychmiastowych gratyfikacji (Oaten, Cheng, 2006).

Przyglądając się specyfice samoregulacji, Evans, Boggero, i Segerstrom (2016) zaproponowali jej analogię do zmęczenia fizycznego, wykazując podobieństwo między zmęczeniem fizycznym a wyczerpaniem zasobów samoregulacji (dalej nazywamy tą teorię zmęczeniową). W jej świetle organizm, który zarejestrował znaczne wydatki energii może podjąć działania mające na celu redukcję tych wydatków aby zabezpieczyć swoje zasoby „na czarną godzinę". Kluczowe w tej sytuacji jest to, że organizm może zacząć oszczędzać energię nawet wtedy, gdy ma jeszcze jej spory zapas. Liczy się sam fakt rejestracji wzmożonego wydatkowania energii, związanym z wysiłkiem fizycznym czy powstrzymywaniem się przed pokusą.

Analizując przytpoczone powyżej badania można oczekiwać, że podobnie podobnie jak mięśnie, samoregulacja zyskuje na treningu długofalowo, ale krótkofalowo może stracić. Długoterminowy zysk polega na zwiększeniu umiejętności do odmawiania sobie krótkoterminowych korzyści w imię realizacji długofalowych planów. Krótkoterminowa strata wynika z poczucia wyczerpania i chęci oszczędzania zasobów umysłowych, niezbędnych do 
efektywnej samoregulacji tu i teraz. Taką hipotezę dodatkowo wspierają dane wskazujące, że oosby u których osłabiono siły samoregulacji przejawiają silniejszą reakcję obszaru mózgu odpowiedzialnego za rejestrowanie wartości nagrody, przy jednoczesnym spadku powiązania tego obaszaru z obszarem odpowiedzialnym za kontrolę poznawczą (Wagner, Altman, Boswell, Kelley,, Heatherton, 2013). Przypuszczamy zatem, że wyczerpane fizycznie osoby będą redukowały wydatki energii an samoregulację, co w efekcie spowoduje wzrost ich impulsywności w wyborach międzyokresowych.

Aby uzasadnić nasze przypuszczenia omówimy czynniki, które kształtują siłę dyskontowania, oraz omówimy cechy impulsywności rozumianej jako cecha lub jako stan.

\section{Czynniki wplywające na sitę dyskontowania}

Badacze - głównie ekonomiści - ustalili szereg czynników, które kształtują stopę dyskontową. Są to: (1) cechy problemu, (2) jego prezentacji oraz (3) cechy decydenta. W związku z tym, że ekonomia w mniejszym stopniu kładzie nacisk na różnice indywidualne decydentów, a większym stopniu koncentruje się na cechach obiektywnych problemu, wiele wiadomo o tej pierwszej grupie, nieco więcej o grupie drugiej, a chyba najmniej o grupie trzeciej.

W tej pierwszej kategorii, koncentruącej się na cechach rozważanego problemu, znajdziemy min. zjawiska takie jak efekt znaku, wskazujący, że silniej dyskontujemy zyski niż straty (Thaler, Shefrin, 1981); efekt wielkości kwoty, wskazujący, że silniej dyskontujemy mniejsze kwoty niż te większe (Benzion, Rapoport, Yagil, 1989) czy efekt kierunku, wskazujący, że oczekujemy większej rekompensaty za odroczenie danej korzyści niż jesteśmy skłonni zapłacić za jej wcześniejsze uzyskanie (Loewenstein, 1988). W kontekście siły dyskontowania znaczenie ma też to, jakiego rodzaju wypłata jest odraczana: finansowa, dotycząca jedzenia, seksu czy używek (Holt, 
Newquist, Smits, Tiry, 2014). Istnieją dość solidne podstawy by sądzić, że siła dyskontowania jest różna ze względu na subiektywną atrakcyjność wypłaty: im atrakcyjniejsza wypłata, tym silniej ją dyskontujemy (Tsukayama, Duckworth, 2010). Na przykład uzależnieni od narkotyków badani silniej dyskontują używki warte tysiąc dolarów niż ich równowartość w gotówce (Madden i in., 1997) $)^{1}$

Druga kategoria czynników mających wpływ na stopę dyskontową obejmuje sformułowanie problemu, np. instrukcję. Ludzie wykazują mniejszą impulsywność, gdy pytani są o wyobrażenie sobie, co na ich miejscu zrobiłby ekspert (Białek, Sawicki, 2014), natomiast większą, gdy wyobrażają sobie, jak postapiłby na ich miejscu laik (Białaszek i in., 2016). Ponadto, ludzie przywiązują się do (choćby nieumyślnie) narzuconego punktu odniesienia. Na przykład zapytanie czy „wolisz mniejszą wypłatę dziś czy większą później” przywołuje najpierw obraz natychmiastowej wypłaty i w efekcie zwiększa stopę dyskontową, niż gdyby zapytać „,wolisz więcej później czy mniej teraz?” (Weber i in., 2007). Taki sam efekt uzyskać można, gdy w szeregu wyborów podobnych do negocjacji (tzw. procedura adjusting) jedna opcja jest stała, a druga dopasowuje się do niej. W takim wypadku opcja stała staje się punktem odniesienia (Sawicki, Białek, 2016).

W trzeciej kategorii czynników kształtujących wybory międzyokresowe możemy znaleźć wpływ refleksyjnego stylu poznawczego (Białek, Sawicki, 2018; Noori, 2016; Toplak, West,

\footnotetext{
${ }^{1}$ Ze względu na to, że domena wypłat może stanowić potencjalny moderator badanych zależności (Holt, Newquist, Smits, \& Tiry, 2014), zdecydowaliśmy się zawęzić nasze badanie do jednej domeny: finansowej. Nasza praca dotyczy zatem nie tyle ogólnego wpływu zmęczenia na siłę dyskontowania, co jedynie na dyskontowanie wypłat finansowych - preferencję dla większych, ale odroczonych wypłat pieniężnych w stosunku do wypłat mniejszych, ale natychmiastowych. Im silniejsze dyskontowanie, tym większa preferencja dla mniejszych, natychmiastowych wypłat.
} 
Stanovich, 2011), inteligencji (Shamosh, Gray, 2008), oraz zmiennych socjodemograficznych takich jak wiek (Steinberg i in., 2009), dochód czy wykształcenie (Reimers i in., 2009).

\section{Impulsywność jako stan i cecha}

Stopa dyskontowa często uznawana jest za psychologiczną miarę impulsywności, a jej wielkość pozwala przewidywać różnorakie zachowania, np. zadłużanie się (Ikeda, Kang, 2015; Laibson, Repetto, Tobacman, 2003), skłonności hazardowe (Alessi, Petry, 2003) czy uzależnienia od substancji psychoaktywnych (Bretteville-Jensen, 1999). Stopa dyskontowa jest różna dla różnych osób, ale ponadto nie jest stała dla jednostki - ludzie są czasem bardziej, a czasem mniej impulsywni. Bardziej impulsywni stają się na przykład wtedy, gdy odraczają większe lub bardziej atrakcyjne dla siebie wypłaty.

Szeroko dyskutowanym w psychologii modelem wyjaśniającym dlaczego ludzie przejawiają różną impulsywność jest siłowy model samoregulacji (strength model of self-regulation). Podstawowym założeniem modelu jest to, że samokontrola bazuje na jakiejś puli zasobów, które osoba zużywa gdy powstrzymuje się przed pokusą. Kiedy owe zasoby ulegają wyczerpaniu, znacznej redukcji ulega też zdolność do samokontroli - nastepuje tak zwane wyczerpanie ego (Baumeister, Vohs, 2016). W rezultacie wyczerpania ego ludzie słabiej kontrolują swoje zachowanie, stają się bardziej impulsywni i potencjalnie silniej dyskontują.

Ludzie różnią się zarówno ogólną pulą zasobów, które służą samoregulacji (Baumeister, Gailliot, DeWall,, Oaten, 2006; Tangney, Baumeister, Boone, 2004), oraz tym ile z tych zasobów mają w danej chwili do dyspozycji. Mówimy zatem zarówno o cesze jaką jest ogólna zdolność do samoregulacji, jak i o stanie, jakim jest chwilowa zdolność do samoregulacji. Siłę samoregulacji rozumianej jako cecha można zwiększyć poprzez jej trening, na przykład poprzez regularne 
ćwiczenia fizyczne (Oaten, Cheng, 2006) czy monitorowanie swojej sytuacji finansowej (Oaten, Cheng, 2007). Ćwiczenia fizyczne mają zatem potencjalnie pozytywny wpływ na impulsywność rozumianej jako stała właściwość danej jednostki. Nie jest jednak jasne jakie konsekwencje dla siły dyskontowania rozumianej jako stan może mieć chwilowy wysiłek.

W świetle modelu siłowego samoregulacji zmęczenie ma negatywny wpływ na zdolność do samoregulacji, ale dopiero wtedy gdy decydent zarejestruje brak zasobów energetycznych. Z kolei w świetle omawianej wcześniej analogii samokontroli do wyczerpania fizycznego organizm ogranicza wydatki energii nawet wtedy gdy ma jej dość duży zapas (Evans i in., 2016). To znaczy, że nawet osoba która która ma ku temu niezbędne zasoby i mogłaby skutecznie odraczać gratyfikację, zmęczona będzie dyskontować silniej. Po prostu zdecydowała się nie wydatkować tych zasobów w celu samoregulacji. Niezależnie czy model siłowy czy zmęczeniowy samoregulacji są prawdziwe, oczekujemy wzrostu stopy dyskontowej u osób, które będą zmęczone fizycznie.

Istnieje jednak kilka innych powodów by oczekiwać wzrostu siły dyskontowej natychmiast po wysiłku, a które nie odwołują się do modelów zasobowych samoregulacji. Jeden z takich powodów nazwaliśmy generalizacją deprywacji, a ilustruje go badanie, które przeprowadzili Sawicki i Eliasz (2011). Osoby które brały udział w omawianym eksperymencie zostały podzielone na dwie grupy. Badani: jedna połowa na czczo (bez śniadania) a druga połowa zaraz po posiłku, dokonywali serii wyborów między natychmiastowymi a odroczonymi zyskami. Okazało się, że osoby przed posiłkiem były bardziej impulsywne i decydowały się na natychmiastową gratyfikację, natomiast osoby najedzone potrafiły oprzeć się pokusie i odłożyć w czasie nagrodę. Badanie sugeruje, że 
deprywacja jednej potrzeby (tu: głód), która wywołuje motywację do jej natychmiastowego zaspokojenia, może generalizować się na impulsywność w innych domenach (tu: finanse).

W kontekście przytoczonego powyżej badania Sawickiego i Eliasz wydaje się, że analogicznie może działać wysiłek fizyczny. Osoby zmęczone intensywnym treningiem będą odczuwały potrzebę (np. odpoczynku, oraz być może głód) którą trzeba natychmiast zaspokoić. Ta niezaspokojona potrzeba generalizuje się na impulsywność w innych wyborach. Wydaje się zatem uzasadnione by przypuszczać, że osoby które podejmowały wzmożoną aktywność fizyczną będą silniej dyskontować wypłaty finansowe.

Podobny wniosek można wysnuć w oparciu o przypuszczenie, że badani mogą po prostu mieć silne skojarzenia między podejmowaniem wysiłku a tym, że przysługuje im za to nagroda. Skoro zatem badany podjął wysiłek fizyczny, może uznać, że należy mu się natychmiastowa gratyfikacja.

Inne uzasadnienie stawianej hipotezy bierze się z obserwacji, że badani czasem dokonują mylnej atrybucji swojego pobudzenia. Na przykład osoby które przeszły przez most linowy (w porównaniu do osób które przeszły zwykłym mostem) oceniają osobę na drugim brzegu jako atrakcyjniejszą (Dutton, Aron, 1974). Podobny efekt zaobserwowano w przypadku pobudzenia wywołanego muzyką (Marin, Schober, Gingras, Leder, 2017). Przypuszczalnie, zwiększona atrakcyjność obserwowanej osoby wynika z faktu, że badani błędnie zinterpretowali pobudzenie wywołane przejściem przez most lub słuchaniem muzyki jako pobudzenie wywołane widokiem innej osoby. W świetle powyższych obserwacji, można przypuszczać, że osoby które są pobudzone w wyniku świeżo ukończonego wysiłku mogą mylnie interpretować swoje pobudzenie jako reakcję na atrakcyjność oferowanej wypłaty, co w efekcie prowadzi do subiektywnego wzrostu 
atrakcyjności rozważanych wypłat. Zwiększona atrakcyjność wypłaty, jak już wspomniano, powoduje zwiększenie impulsywności (Tsukayama, Duckworth, 2010).

Podsumowując, stawiamy hipotezę, że zaraz po wysiłku fizycznym osoby będą silniej dyskontowały wypłaty finansowe, niż robiły to gdy były wypoczęte.

\section{Badanie}

\subsection{Określenie liczebności próby}

Istnieje kilka powodów, dla których badacze nie są w stanie wykryć realnie istniejących związków między zmiennymi. Jednym z nich jest niedostateczna liczba obserwacji. Pewne efekty są na tyle małe, że można je wykryć tylko dzięki dużej liczbie obserwacji; niedostateczna liczba obserwacji spowoduje, że obserwowana siła związku między zmiennymi będzie statystycznie nieodróżnialna od braku związku. Rozwiązaniem nie jest jednak zbiórka bardzo dużej liczby danych, gdyż prowadzi to do uzyskania statystycznie istotnych związków między zmiennymi o niewielkiej sile i minimalnym znaczeniu teoretyczno-praktycznym (Ellis, Steyn, 2003; Coe, 2002).

Aby określić optymalną liczbę obserwacji niektórzy badacze posługują się analizą mocy (power analysis) - wyliczają taką liczbę badanych, która z np. 80\% szansą pozwoli wykryć związek między zmiennymi, zakładając że on istnieje i ma pewną siłę. Im mniejsza siła, tym więcej obserwacji należy zebrać. Analiza mocy ma jednak pewne ograniczenia (Kruschke, 2010). Badacze nierzadko mają problem z jednoznacznym określeniem jakiej wielkości efektu oczekują, choćby dlatego, że prowadzą badania nad nieznanym dotąd efektem. Ponadto, trudno jest też określić jaki przedział ufności należy przydzielić badanemu efektowi. Jeśli bowiem dany efekt miałby 
oczekiwaną siłę $d=0,4$, to czy obserwacja efektu o tym samym kierunku, ale sile $d=0,15$ potwierdza czy zaprzecza testowanej hipotezie? Z jednej strony efektowi bliżej do hipotezy o nieistnieniu testowanego efektu (realny wynik leży bliżej $d=0$ niż $d=0,4$ ), z drugiej strony stanowi potwierdzenie, że między zmiennymi zachodzi związek.

W związku z coraz lepiej rozumianymi przez badaczy problemami z klasyczną statystyką opartą na testowaniu hipotezy zerowej (Karpe, 2017), w niniejszej pracy postanowiliśmy zastosować podejście Bayesowskie do określania minimalnej liczby obserwacji (Kruschke, 2013; Dienes, 2016). Parametr bayesowski (Bayes Factor) mierzy siłę dowodu na rzecz danego modelu w stosunku do porównywanych modeli (Domurat, Białek, 2016). Na przykład gdy testujemy hipotezę, H1: że dwie grupy różnią się od siebie pod względem jakiegos parametru (vs H0: że są sobie równe) $\mathrm{B}_{10}=8$ sugeruje, że zebranie danych takie jak analizowane jest osmiokrotnie bardziej prawdopdobne przy założeniu że model $\mathrm{H} 1$ jets prawdziwy, niż przy założeniu że to model $\mathrm{H} 0$ jest prawdziwy. $\mathrm{Z}$ kolei $\mathrm{B}_{01}=8$ oznacza, że zebranie nanlizowanych danych jets ośmiokrotnie bardziej prawdopodobne przy założeniu braku różnic między grupami. Jest to duża różnica dla interpretacji danych, ponieważ tylko parametr bayesowski pozwala potwierdzić hipotezę zerową; statystyki $p$ pozwalaja jedynie odrzucić hipotezę zerową lub nie, nigdy nie stanowiąc jednak dowodu na jej rzecz (Dienes, 2014; Jarmakowska-Kostrzanowska, 2016). Należy pamiętać, że B nie stanowi jednak miary obiektywnego dowodu na rzecz modelu, a jedynie jego relatywną przewagę nad porównywanym z nim modelem. Oba modele mogą być jednak nietrafne, a po prostu jeden gorszy od drugiego.

Zbierając dane obserwowaliśmy relatywną siłę dowodu wspierającego testowaną hipotezę (o istnieniu wpływu zmęczenia na siłę dyskontowania) wobec modelu zerowego, a za rozstrzygające 
uznaliśmy trzykrotnie większe wsparcie przez dowody któregoś z modeli. Innymi słowy oczekiwaliśmy, że uzyskanie danych takich jak zebrane będzie conajmniej trzykrotnie bardziej prawdopodobne przy przyjęciu że model zakładający wzrost impulsywności w wyniku zmęczenia jest prawdziwy niż przy modelu zakładającym brak takiego efektu. Przerwaliśmy zbiórkę danych gdy osiągnęliśmy co najmniej taką siłę dowodów.

Często sstawianym zarzutem wobec procedury testowania danych „na bieżąco” i przerwania zbiórki gdy osiągnie się upragniony wynik jest to, że statystyka $p$ dla dwóch niepowiązanych zmiennych może przyjmować każdą wartość (Benjamini, Yekutieli, 2001). Z tego wynika, że test statystyczny będzie ostatecznie wskazywać wartość $p<0,05$ jeśli użyje się go odpowiednio wiele razy. Należy jednak podkreślić, że testy bayesowskie są stosunkowo niewrażliwe na wielokrotne testowanie, gdyż siła dowodu rośnie monotonicznie wraz ze zebranymi danymi. Nie ma zatem dużego ryzyka że wielokrotne sprawdzanie wartości B przekroczy wartość krytyczną gdy testowany efekt w rzeczywistości nie istnieje (Kruschke, 2010).

\subsection{Badani}

W badaniu udział wzięło 63 ochotników (28 kobiet), którzy uczestniczyli w zajęciach w jednej $\mathrm{z}$ warszawskich siłowni. Wiek badanych niestety nie był kontrolowany. Uczestnicy rekrutowani byli przez autorkę nieniejszego tekstu gdy wchodzili do budynku siłowni oraz informowani o charakterze i celu badania. Badani nie byli wynagradzani za swój udział, a po zakończeniu badania uzyskiwali szczegółową informację na temat celu przeprowadzanych badań.

\subsection{Materialy}

\subsubsection{Dyskontowanie}


Do pomiaru siły dyskontowania użyto Monetary Choice Questionnaire opracowanego przez Kirbiego i Markowica (1996), a składającego się z 27 pytań. Badani mieli do wyboru mniejsze natychmiastowe wypłacenie kwoty lub opóźnione większe wynagrodzenie, np. w pierwszym pytaniu badani mieli do wybrania $54 \$$ dzisiaj lub $55 \$$ za 117 dni. Aby dokonać polskiej adaptacji zmieniliśmy oznaczenie waluty z \$ na PLN, pozostawiając te same wartości nominalne. Wydaje się, że poprzez ten zabieg subiektywna wartość wypłat była podobna do oryginalnej (stanowiła podobny procent średniej pensji), a zachowywała swoje wartości nominalne. Kwestionariusz podzielona na trzy wielkości nagród: małe ( 25 do 35 zł), średnie (50 do 60 zł) i duże ( 75 do 85 zł). W każdej kategorii, próby zostały tak dobrane, aby odpowiadały każdemu z dziewięciu predefiniowanych poziomów parametru $k$.

W oparciu o serię wyborów, używając do tego narzędzia stworzonego przez Kaplan i in. (2014), każdemu z badanych wyliczono parametr dyskontowy $k$ oraz spójnośc jego odpowiedzi. Zgodnie z zaleceniami autorów narzędzia z ostatecznych analiz wykluczono dwie osoby, których spójnośc była niższa niz $80 \%$, pozostawiając w analizie $n=61$ osób (w tym 28 kobiet).

\subsubsection{Aktywność fizyczna}

Badani uczestniczyli w zajęciach na siłowni wykonywanych pod okiem instruktora, dobranych stosownie do ich planu treningowego. Oznacza to, że każdy badany wykonywał ćwiczenia o innej intensywności, ale dobrane tak, by zoptymalizować wysiłek adekwatnie do swoich możliwości i aktualnej formy fizycznej.

\subsection{Procedura}


Badanym rozdano dwa kwestionariusze MCQ, jeden oznaczony jako PRE a drugi POST, odpowiadając pre- $\mathrm{i}$ posttestowi $\mathrm{w}$ procedurze badania $\mathrm{z}$ powtórzonym pomiarem. Oba kwestionariusze badani wypełniali w szatni: pierwszą część przed, a drugą po zakończeniu ćwiczeń. Aby uniknąć zbyt słabego efektu zmęczenia prosiliśmy badanych którzy planowali ćwiczyć krócej niż 30 minut, by nie byli brali udziału w badaniu.

\subsection{Wyniki}

Pełną bazę danych z raportowanego badania można pobrać ze strony https://osf.io/kq4mz/. Rysunek 1 przedstawia stopę dyskontową obserwowaną przed i po ćwiczeniach fizycznych.

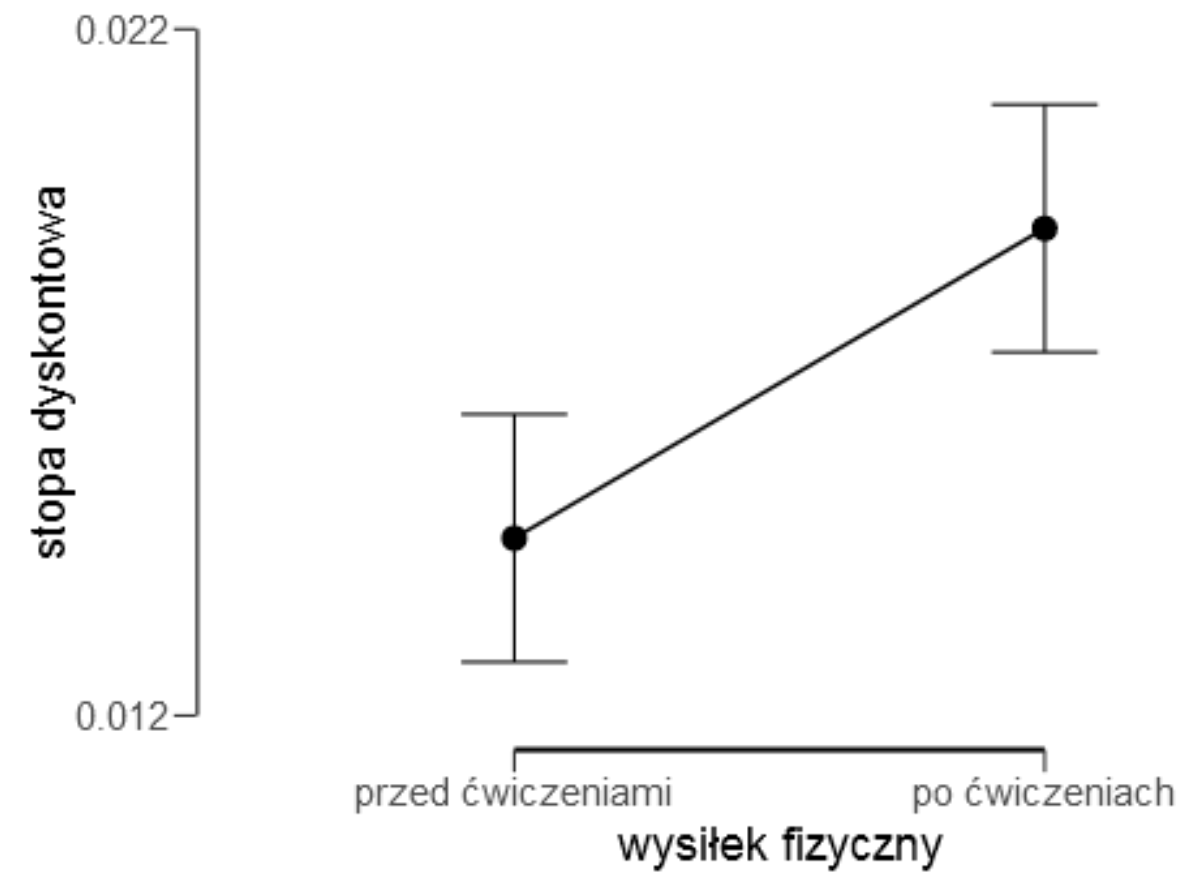

Rys. 1. Średnie dzienne stopy dyskontowe przed i po wysiłku. Słupki błędu przedstawiają 95\% przedział ufności średniej. 
Bayesowska analiza wariancji z powtarzanym pomiarem dla grupy badanych po usunięciu osób niespójnych ( $n=61)$ wskazuje na $\mathrm{B}_{10}=40,13$. Uzyskany dowód należy uznać za silnie wspierający hipotezę o wzroście stopy dyskontowej w wyniku wysiłku fizycznego (Wetzels i in., 2011). Warto nadmienić, że dla całej zbadanej grupy $(n=63)$ czynnik bayesowski (którym kierowalismy się ustalając koniec zbiórki danych) osiaga wartośc $\mathrm{B}_{10} \approx 3$. Zatem usunięcie dwóch osób znacząco zwiększyło siłę zebranego dowodu, ale nie zmieniło kierunku raportowanych wyników ${ }^{2}$.

\section{Dyskusja}

Przedstawiony quasi-eksperyment wykazał, że w zmęczenie fizyczne spowodowało wzrost impulsywności w domenie finansowych wyborów międzyokresowych. Zebrane dowody potwierdzają zmiany na poziomie behawioralnym, ale nie pozwalają niestety jednoznacznie określić, jaki proces psychologiczny za nie odpowiada.

Zaproponowaliśmy kilka potencjalnych mechanizmów, które mogłyby odpowiadać za ten efekt: zmęczeniowy oraz siłowy model samoregulacji, skojarzenie wysiłku z przysługującą nagrodą, generalizację deprywacji, oraz błędną atrybucję pobudzenia. Kluczowym jest zatem znalezienie metody która rozstrzygnie pomiędzy wyjaśnianiami dla obserwowanego związku impulsywności i zmęczenia fizycznego w kontekście modeli samoregulacji: modelu siłowego (Baumeister, Vohs, 2016) i zmęczeniowego (Evans, Boggero, Segerstrom, 2016) samoregulacji. Przypomnijmy - ten pierwszy przewiduje spadek samokontroli wtedy, gdy zasoby energetyczne

\footnotetext{
${ }^{2}$ Warto zauważyć, że wyniki odrzuconych osób także pasują do stawianej hipotezy, gdyż ich średnia stopa dyskontowa przed wysiłkiem wynosiła $k=0,031$ a po wysiłku $k=0,087$. Za spadek siły dowodu przy uwzględnieniu tych osób odpowiada wysokie odchylenie standardowe ich stopy dyskontowej.
} 
ulegną wyczerpaniu; ten drugi przewiduje spadek samokontroli gdy organizm zarejestruje wzmożone wydatkowanie energii, ale niezależnie od tego jak dużą posiada jej rezerwę.

Jedną z takich metod byłoby kontolowanie rodzaju wykonywanych ćwiczeń i formy fizycznej badanych, co pozwoliłoby określić skalę zmęczenia badanych. Poziom zmęczenia umożliwiłby przewidywanie stopnia zmiany stopy dyskontowej, co z kolei dałoby możliwość zweryfikowania przypuszczeń przedstawionych przez nas teorii. Model zmęczeniowy samokontroli przewiduje bowiem, że istnieje pewna ilość wysiłku która spowoduje, że jest rejestrowana jako znaczna, i w efekcie powoduje spadek samokontroli (wzrosty stopy dyskontowej). Zależność między zmęczeniem a dyskontowaniem byłaby krzywoliniowa. Model siłowy oraz model błędnej atrybucji pobudzenia przewidywałyby liniowy związek zmęczenia i stopy dyskontowej, gdyż wraz ze wzrostem zmęczenia, odczuwamy coraz większe pobudzenie i wyczerpanie zasobów energetycznych.

Innym sposobem porównania modeli samokontroli jest obserwacja tempa zmiany stopy dyskontowej w wyniki zmęczenia wśród osób bardziej i mniej impulsywnych. Celem byłoby sprawdzenie, czy wzrost siły dyskontowania obserwujemy wtedy gdy zasoby energetyczne się kończą (zaobserwujemy wtedy, że stopa dyskontowa rośnie szybciej u osób bardziej impuslywnych, gdyz mają one mniej zasobów niezbędnych do samokontroli), czy też jej wzrost jest następstwem samego faktu wzmożonego wydatku energii (zaobserwujemy wtedy porównywalny wzrost stopy dyskontowej u osób impuslwynych oraz nieimpuslwynych).

Przedstawione w niniejszym tekście wyniki mogą zainteresować także praktyków, dla których potencjalnie istotne jest to, że ich kienci zaraz po wysiłku mogą bardziej ulegać pokusom. Wyobraźmy sobie plan odchudzania klienta, który zawiera elementy aktywności fizycznej na siłowni. Jeśli prawdą jest, że wraz ze zmęczeniem chwilowo rośnie stopa dyskontowa, to istnieje 
poważne zadrożenie dla efektywności takiej terapii. Klient może bowiem natychmiast po zakończeniu ćwiczeń ulec pokusie zjedzenia słodyczy czy wypicia wysokosłodzonego napoju, znacznie redukując w ten sposób korzyść z właśnie zakończonych ćwiczeń. Warto zatem podjąć działania profilaktyczne poprzez włączenie czasu na regenerację i odzyskanie pełnej sprawności samokontroli do samego procesu ćwiczenia. Podobnie, istnieje uzasadnione przypuszczenie, że osoba która przechodzi odwyk od używek (np. alkoholu) wymaga szczególnego wsparcia w abstynencji $\mathrm{w}$ momencie powrotu do pracy i pierwszych oznak związanego $\mathrm{z}$ tym faktem zmęczenia fizycznego.

Podsumowując, zaobserwowany efekt krótkotrwale zwiększonej impulsywności w wyniku wysiłku fizycznego stanowi wyzwanie dla teorii dyskontowania oraz szerzej, teorii samoregulacji. Wyjaśnienie dlaczego zachodzi obserwowany efekt może stanowić metodę weryfikacji konkurencyjnych modeli samokontroli - ten model który lepiej pozwala wyjaśniać dlaczego w wyniku ćwiczeń fizycznych obserwujemy wzrost samokontroli jako cechy przy jednoczesnym chwilowym spadku samokontroli jako stanu, ten lepiej oddaje naturę rzeczy i bliższy jest prawdy. 


\section{Bibliografia}

Alessi, S., Petry, N. (2003). Pathological gambling severity is associated with impulsivity in a delay discounting procedure. Behavioural Processes, 64, 345-354.

Baumeister, R. F.,, Vohs, K. (2016). Strength model of self-regulation as limited resource: Assessment, controversies, update. Advances in Experimental Social Psychology, 54, 67-127.

Baumeister, R. F., Gailliot, M., DeWall, C. N.,, Oaten, M. (2006). Self-regulation and personality: How interventions increase regulatory success, and how depletion moderates the effects of traits on behavior. Journal of Personality, 74, 1773-1802.

Benjamini, Y.,, Yekutieli, D. (2001). The control of the false discovery rate in multiple testing under dependency. Annals of Statistics, 29, 1165-1188.

Benzion, U., Rapoport, A., Yagil, J. (1989). Discount rates inferred from decisions: An experimental study. Management Science, 35, 270-284.

Białaszek, W., Bakun, P., McGoun, E., Zielonka, P. (2016). Standing in Your Peer's Shoes Hurts Your Feats: The Self-Others Discrepancy in Risk Attitude and Impulsivity. Frontiers in Psychology, 7, 197.

Białek, M., Sawicki, P. (2014). Can taking the perspective of an expert debias human decisions? The case of risky and delayed gains. Frontiers in Psychology, 5, 989.

Białek, M., Sawicki, P. (2018). Cognitive reflection effects on time discounting. Journal of Individual Differences, advance online publication.

Bretteville-Jensen, A. L. (1999). Addiction and discounting. Journal of Health Economics, 18, 393407. 
Coe, R. (2002). It's the effect size, stupid: What effect size is and why it is important. Paper presented at the British Educational Research Association, Exeter, UK, 12-14 September 2002.

Dienes, Z. (2014). Using bayes to get the most out of non-significant results. Frontiers in Psychology, 5, 781.

Dienes, Z. (2016). How Bayes factors change scientific practice. Journal of Mathematical Psychology, 72, 78-89.

Domurat, A., Białek, M. (2016). Dowodzenie hipotez za pomocą czynnika bayesowskiego (Bayes Factor): przykłady użycia w badaniach empirycznych. Decyzje, 26, 109-141.

Dutton, D. G.,, Aron, A. P. (1974). Some evidence for heightened sexual attraction under conditions of high anxiety. Journal of Personality and Social Psychology, 30, 510-517.

Ellis, S. M.,, Steyn, H. S. (2003). Practical significance (effect sizes) versus or in combination with statistical significance (p-values). Management Dynamics, 12, 51-53.

Evans, D. R., Boggero, I. A.,, Segerstrom, S. C. (2016). The nature of self-regulatory fatigue and “ego depletion" lessons from physical fatigue. Personality and Social Psychology Review, 20, 291-310.

Holt, D. D., Newquist, M. H., Smits, R. R.,, Tiry, A. M. (2014). Discounting of food, sex, and money. Psychonomic Bulletin and Review, 21, 794-802.

Houben, K., Jansen, A. (2011). Training inhibitory control. A recipe for resisting sweet temptations Appetite, 56, 345-349. 
Ikeda, S., Kang, M. I. (2015). Hyperbolic discounting, borrowing aversion and debt holding. The Japanese Economic Review, 66, 421-446.

Jarmakowska-Kostrzanowska, L. (2016). W statystycznym matriksie: kontrowersje wokół testowania istotności hipotezy zerowej (null hypothesis significance testing, NHST) oraz p-wartości.. Psychologia Społeczna, 11, 458-473.

Kaplan, B. A., Lemley, S. M., Reed, D. D., Jarmolowicz, D. P. (2014). 21-and 27-Item Monetary Choice Questionnaire Automated Scorers. Papers of the Center for Applied Neuroeconomics, University of Kansas.

Karpe, K. (2017). In chase of statistically significant result. Consequences of widespread use of NHST (null hypothesis significance testing) in psychology. Nauka, 1, 143-156.

Kirby, K. N., Maraković, N. N. (1996). Delay-discounting probabilistic rewards: Rates decrease as amounts increase. Psychonomic Bulletin, Review, 3, 100-104.

Kruschke, J. K. (2010). What to believe: Bayesian methods for data analysis. Trends in Cognitive Sciences, 14, 293-300.

Kruschke, J. K. (2013). Bayesian estimation supersedes the t test. Journal of Experimental Psychology: General, 142, 573.

Laibson, D. (1997). Golden eggs and hyperbolic discounting. The Quarterly Journal of Economics, $112,443-478$.

Laibson, D., Repetto, A., Tobacman, J. (2003). TImperfect Common Knowledge and the Effects of Monetary Policy. In R. F. Ph. Aghion, J. Stiglitz, and M. Woodford (Ed.), Knowledge, Information and Expectations in Modern Macroeconomics: In Honor of Edmund S. Phelps. Princeton: Princeton University Press. 
Loewenstein, G. F. (1988). Frames of mind in intertemporal choice. Management Science, 34, 200214.

Madden, G. J., Petry, N. M., Badger, G. J.,, Bickel, W. K. (1997). Impulsive and self-control choices in opioid-dependent patients and non-drug-using control patients: Drug and monetary rewards. Experimental and Clinical Psychopharmacology, 5, 256-262.

Marin, M. M., Schober, R., Gingras, B.,, Leder, H. (2017). Misattribution of musical arousal increases sexual attraction towards opposite-sex faces in females. PLoS One, 12, e0183531.

Moffitt, T. E., Arseneault, L., Belsky, D., Dickson, N., Hancox, R. J., Harrington, H., . . Caspi, A. (2011). A gradient of childhood self-control predicts health, wealth, and public safety. Proceedings of the National Academy of Sciences of the United States of America, 108, 26932698.

Muraven, M., Baumeister, R. F.,, Tice, D. M. (1999). Longitudinal improvement of self-regulation through practice: Building self-control strength through repeated exercise. The Journal of Social Psychology, 139, 446-457.

Noori, M. (2016). Cognitive reflection as a predictor of susceptibility to behavioral anomalies. Judgment and Decision Making, 11, 114-120.

Oaten, M., Cheng, K. (2006). Longitudinal gains in self-regulation from regular physical exercise. British Journal of Health Psychology, 11, 717-733.

Oaten, M., Cheng, K. (2007). Improvements in self-control from financial monitoring. Journal of Economic Psychology, 28, 487-501. 
Reimers, S., Maylor, E. A., Stewart, N., Chater, N. (2009). Associations between a one-shot delay discounting measure and age, income, education and real-world impulsive behavior. Personality and Individual Differences, 47, 973-978.

Sawicki, P., Białek, M. (2016). Side Effects in Time Discounting Procedures: Fixed Alternatives Become the Reference Point. PloS one, 11, e0165245.

Sawicki, P., Eliasz, E. (2011). Dyskontowanie odroczonych wypłat przed i po jedzeniu. Decyzje, $15,61-71$.

Shamosh, N. A., Gray, J. R. (2008). Delay discounting and intelligence: A meta-analysis. Intelligence, 36, 289-305.

Steinberg, L., Graham, S., O’Brien, L., Woolard, J., Cauffman, E., Banich, M. (2009). Age differences in future orientation and delay discounting. Child Development, 80, 28-44.

Tangney, J. P., Baumeister, R. F.,, Boone, A. L. (2004). High self-control predicts good adjustment, less pathology, better grades, and interpersonal success. Journal of Personality, 72, 271-324.

Thaler, R. H., Shefrin, H. M. (1981). An economic theory of self-control. Journal of Political Economy, 89, 392-406.

Toplak, M. E., West, R. F., Stanovich, K. E. (2011). The Cognitive Reflection Test as a predictor of performance on heuristics-and-biases tasks. Memory, Cognition, 39, 1275-1289.

Tsukayama, E.,, Duckworth, A. L. (2010). Domain-specific temporal discounting and temptation. Judgment and Decision Making, 5, 72-82.

Wagner, D. D., Altman, M., Boswell, R. G., Kelley, W. M., Heatherton, T. F. (2013). Selfregulatory depletion enhances neural responses to rewards and impairs top-down control. Psychological Science, 24, 2262-2271. 
Weber, E. U., Johnson, E. J., Milch, K. F., Chang, H., Brodscholl, J. C., Goldstein, D. G. (2007). Asymmetric discounting in intertemporal choice: A query-theory account. Psychological science, $18,516-523$.

Wetzels, R., Matzke, D., Lee, M. D., Rouder, J. N., Iverson, G. J., Wagenmakers, E.-J. (2011). Statistical evidence in experimental psychology: An empirical comparison using 855 ttests. Perspectives on Psychological Science, 6, 291-298. 